\title{
Which actors influence student's university orientation in Morocco? An exploratory study with civil engineering students
}

\author{
Youssef Harraki ${ }^{1,{ }^{*}}$, Aniss Moumen ${ }^{1}$,Ahmed Remaida ${ }^{1}$ and DrissGretete ${ }^{1}$ \\ ${ }^{1}$ Laboratory of Engineering Sciences, ENSA Kenitra, IbnTofail University. Morocco.
}

\begin{abstract}
Orientation of students in universities is considered a key factor that affects students academic and professional paths. Indeed, many institutional and political discourse highlights the importance of "orientation" at the University as a palliative failure. However, in Morocco, the guidance procedures are based essentially on academic performance alone. This paper will present a literature review on "University guidance" and a qualitative study with 30 students from a public school of civil engineers in Casablanca. This work focuses on exploring various helpful factors which may improve academic guidance.
\end{abstract}

\section{1 introduction}

University guidance is a crucial moment for students and affects their learning engagement and employability. Indeed, Much research confirms the strong relationship between University guidance, learning engagement and graduate employability. Therefore, it is essential to prepare this orientation with method and organization to avoid pitfalls and risks on making choices [1]. Universities must give more objective information about academic programs and labour market opportunities [5].

In Morocco, National Council for Youth and Futur has highlighted the role of Students' awareness and guidance [3]. Also, according to the Higher Council of Education, Training and Scientific Research [2], a national information and guidance system would be an essential tool for better controlling education systems and adapting to economic and social changes [4].

This study aims to detect various factors that can be useful in improving academic guidance on the transition from the preparatory cycle to the engineering cycle for civil engineering students in Morocco.

* Corresponding author:youssefhrrk@gmail.com, youssef.harraki@uit.ac.ma 


\section{Literature Review}

Many studies conducted in different countries identify factors affecting students in career choices. Many authors studied the orientation in university or University guidance from the personal psychological point of view. Indeed, L. Lardy [8] has identified the factors influencing students' academic success in the first year of a technological university, such as motivational, behavioural, and variables defining the academic programs. According to A. Belhaj [1], Student counselling can be understood through the contributions of psychoanalysis. M. Duru-Bellat [9] presents the Factors and mechanisms of guidance in the French education system. These factors are the weight of the previous school career, the decisive role of demand and the related social inequalities, consistency of orientation decisions, and the role of the social composition of the school environment. Thus, guidance counsellors and psychologists. They work particularly on professional and social representations, modes of operation, and evolutions; furthermore, how each student processes the information to elaborate behaviours consistent with their personnel project.

According to T. Côme [4], to improve the efficiency of the entire higher education system in Morocco and not offend many actors in University, including student organizations, it is necessary to enhance students' engagement and motivation a posteriori and implement participative guidance. For this reason, different researchers have proposed different theories and models, such as the social cognitive theory. Indeed, A. Bandura [10] considers that various sources of information contribute to developing a university guidance model: Personal experiences of success or failure in the activity; vicarious learning and identification with a model; social influence, verbal and nonverbal reinforcement from others; physiological and emotional states associated with the experiences of performing the activity.

\section{Research Methodology}

This qualitative study used interviews with 30 first-year civil engineering students from a public engineering school in Casablanca to analyze the university guidance process during the transition from the preparatory to the engineering cycle.

The interview included 13 semi-structured questions grouped into :

- Questions about students (age, sex, city, previous school, parents profession)

- Question on the role of guidance in academic success

- Question on the choice motivations

- Question on the factors and actors which influence the orientation

- Question on the satisfaction about the actual choice.

The Students interviewed are $75 \%$ male and 25\% female; their age varies between 20 and 22 years. The majority of the students in the engineering cycle have a Baccalaureate SC MATHS A or B $(90 \%)$ with some exceptions that were Physics or Technical $(10 \%)$. Regarding the parents' profession, it varied from functionary $(46 \%)$, private job $(27 \%)$ or liberal work $(27 \%)$, so the social class of most students is the middle-income class. 


\subsection{What is the sources of information for university guidance? And what are the expectations of the students about the guidance?}

Parents, families, society and trends news influence students' academic choice and orientation [6].

From the beginning, all interviewees are unanimous about their dissatisfaction with existing guidance systems. Indeed, the students in Morocco choose their high schools and speciality according to feedbacks and opportunities to complete their curriculum in a foreign country. As a testimony from 22 years old student :

$<<$ Moroccan engineering schools are ranked according to the choice of students, which is measured by rumours or trends! I quote the public school of engineering as an example where I studied. When I was a student, the school launched a double degree convention with a French school so the first four students could finish their engineering cycle in France. Therefore, some students chose any speciality to have the chance to be classified and complete their studies in France $>>$.

We can say that students make choices that they don't like but reconcile their preferences and the opportunities. Concerning the students' expectations from the guidance university system, the interviews highlight the list below :

$$
\begin{aligned}
& <<\text { Help them make the right choice }>> \\
& <<\text { Be involved in their choice }>>\text {. } \\
& <<\text { Find happiness in their choice }>\text {. } \\
& <<\text { first pat for the job they want to do }>>\text {. }
\end{aligned}
$$

\subsection{What is the role of the actors in university guidance ?}

In fact, most of the interviewees said that the orientation should not focus just on one time or one year. Any concerned actor should play a role in the academic orientation, discovering their quality and contributing to the right choice (see table 2). It is necessary to detect in him their quality by noticed it like: $<<$ you are good in.... $>>$ or $<<$ you can be better in .... >>, as an interviewee has indicated.

Table 2. The most cited actors and factors in university guidance.

\begin{tabular}{|l|l|}
\hline \multicolumn{1}{|c|}{ Actors } & \multicolumn{1}{c|}{ Factors } \\
\hline - Supervisors & - Personality \\
- The advisors & - Communication \\
- The laureates & - Emotional \\
-Youtubers & - Creativity \\
- Digital influencers & - Innovation \\
\hline
\end{tabular}

According to the testimony of a student $<<$ the measures to be taken for a good orientation is to have the choice corresponds to my personality, my motivation and my strengths; look for a way to do the work that I love; finally find happiness in what I do >>. 
The sources of inspiration, motivations and difficulties : students perceptions

The sources of inspiration and motivations for students' choice in the engineering cycle are divided between passion, family, recommendations from friends, laureates, and the media and the internet. As students say:

$<<$ my choice was personally based on my passion (since I had many other choices) $>>$.

$<<$ My uncle working at OCP did recommend my choice of civil engineering $>>$.

$<<a$ TV program and internet influence my choice $>>$.

Also, according to the interviewees, the most common difficulties encountered in academic orientation are :

- Lack of information about labour market requirements.

- Lack of information about the training program and the associated professions.

- Some parents impose on their child's which training program to choose.

- After two years of preparation cycle, a student may find himself in a speciality that is not his primary choice but the choice of the system according to scores.

To conclude, the student's satisfaction with their orientation is divided between satisfied $(43 \%)$ and not very satisfied (40\%). However, a part is not satisfied (17\%) with their choice of orientation.

\section{Conclusion and Discussion}

University and professional orientation allow students to plan their career and personnel project during their academic path. A well-oriented student has a better chance to succeed in academic programs and job insertion.

Through this analysis, we can conclude that university orientation has some difficulties, despite the existing efforts. Also, better orientation criteria must result from the student's reflection on his motivations, interests, and project.

So, it is necessary to redefine the guidance university to regulate the flows of students towards the various branches of education of the engineering cycle reasonably and fairly. Also, create the footbridges to change speciality during the training. Also, the supervisors can advise students through interviews to detect their training needs concerning their aptitudes, attitudes and preferences. In the guidance process, the student requires introspection to discover his personality and potentialities [7].

To conclude, the perspective of this work is to propose a model that helps students in their choice, based on :

- Exam marks

- Advice from experts

- Personal traits

- Courses and jobs description

- Social student's background 


\section{References}

1. Belhaj A, F. Benmimoun, “NOVICIAT IJAR, vol. 7, no. 6, pp. 337-348, Jun. 2019, doi: 10.21474/IJAR01/9230.

2. R. Bourqia, H. Bouabid, L. Laila, K. Yassine, and Z. Nawal, "Higher education in Morocco effectiveness, efficiency and challenges of the open access university system: sector report: Higher Council of Education, Training and Scientific Research, Rabat. 2018.

3. CNJA, Information and guidance in the Education-Training system: Realities and perspective. Proceedings of the study day organized by the National Council for Youth and the Future. Rabat: CNJA, 1994.

4. T. Côme and A. Yassine, "Regulated access to the University and student involvement and motivation: the example of Morocco, "Public management and management, vol. Volume $3 / \mathrm{n}^{\circ} 4$, no. 2, pp. 5-26, Oct. 2015.

5. B. Riyami, "Analysis of the effects of ICT on higher education in Morocco in a training context in collaboration with a university" p. 168. 2018.

6. A. Boulahcen, "The process of school guidance in Morocco. A sociological analysis," Sevres International Education Review, no. 38, Art. No. 38, Apr. 2005, DOI: 10.4000/ries. 1427.

7. Standing Committee on Scientific and Technical Research and Innovation, Reform of Higher Education Strategic Perspectives. June 2019, morocco.

8. L. Lardy, P. Bressoux, and L. Lima, "Factors that influence students' success in a technological university program: the case of the first year of study in a DUT GEA," Academic and professional orientation, no. 44/4, Art. No. 44/4, Dec. 2015, DOI: 10.4000/osp.4671.M. Ben Rabha, M.F. Boujmil, M. Saadoun, B. Bessaïs, Eur. Phys. J. Appl. Phys.

9. M. Duru-Bellat and E. Perretier, "L'orientation dans le système éducatiffrançais, au collège et au lycée," p. 74.L. T. De Luca, Propulsion physics (EDP Sciences, Les Ulis, 2009).

10. A. Bandura. M. Rondier, "Auto-efficacité. Le sentiment d'efficacité personnelle," L'orientation scolaire et professionnelle, no. 33/3, Art. no. 33/3, Sep. 2004. 